\title{
Psalm-Singing at Home: The Case of Etienne Mathieu, a Burgundian Protestant
}

\author{
Kathleen Ashley
}

The Biblical psalms have been central to western worship since the Middle Ages, when monks focused their devotions on the psalter and the later medieval laity incorporated them into their Books of Hours. ${ }^{1}$ Roger Wieck points out that 'the great armature for most prayers in the Book of Hours is Psalms. A total of thirty-seven Psalms form the Hours of the Virgin; these did not change. Nor did the seven of the Penitential Psalms or the twenty-two in the Office of the Dead.' ${ }^{2}$ Virginia Reinburg adds that while Books of Hours were 'largely liturgical' (that is, drawn from monastic liturgical offices), they were not supervised by clerical officials. ${ }^{3}$ The psalms of David were even more intensely the devotional centrepiece of sixteenth-century Protestants throughout Europe. ${ }^{4}$ In this essay, my focus is the central role played by the psalter - as translated into French by Clément Marot and Théodore de Bèze - during the French wars of religion between 1561 and $1598 .^{5}$

1 The original version of this essay was presented at the conference on Domestic Devotions in the Early Modern World, 1400-180o, the University of Cambridge, 9-11 July 2015. I would like to acknowledge the contributions of my partner in the archives, John Reuter.

2 Wieck R., Painted Prayers: The Book of Hours in Medieval and Renaissance Art (New York: 1997) 10. On the development of Books of Hours for the laity from monastic devotional books, see also Duffy E., Marking the Hours: English People and Their Prayers, 1240-1570 (New Haven - London: 2006) 3-52.

3 Reinburg V., French Books of Hours: Making an Archive of Prayer, c. 1400-160o (Cambridge: 2012) 15-20.

4 See Craig J., "Psalms, groans and dogwhippers: The soundscape of worship in the English parish church, 1547-1642", in Coster W. - Spicer A. (eds.), Sacred Space in Early Modern Europe (Cambridge: 2005) 104-108. Using churchwardens' accounts of London parishes, Craig documents the popularity of psalm-singing: 'It would be hard to underestimate the popularity of singing metrical psalms and as difficult to estimate the influence these verses had upon popular Protestantism at the parish level' (108).

5 Austern L.P. - McBride K.B. - Orvis D.L., "Introduction", in Austern L.P. - McBride K.B. Orvis D.L. (eds.), Psalms in the Early Modern World (Burlington, VT - Farnham: 2011) offers a fascinating, wide-ranging survey of the 'Psalms' movement across national boundaries and confessional divides that 'inscribes a map of early modern travel, commerce and cultural exchange', which, the editors point out, challenges the historical narratives of that time. On the

(C) KATHLEEN ASHLEY, 2019 | DOI:10.1163/9789004375888_005

This is an open access chapter distributed under the terms of the prevailing CC-BY-NC-ND License at the time of publication. 
As early as the 1550 s, singing the psalms in the vernacular rather than the orthodox Latin version became the identifying mark of a Huguenot (French Protestant) and a trigger for repression of the group that Catholics referred to as the 'Religion Prétendue Réformée' (the so-called Reformed Religion). ${ }^{6}$ Typically, attention was drawn to Huguenots by their public psalm-singing in the vernacular - often while walking in the street in groups. One of the earliest and best-publicized incidents took place in Lyon in 1551, when a group of artisans and menu peuple (common people) marched through the city centre 'shouting insults against the clergy and singing the psalms in French in a loud and offensive manner.7 By 1558 in Paris, several thousand Protestants gathered each evening at the Pré-aux-Clercs to sing the psalms. ${ }^{8}$ It is difficult to see these numerous incidents reported in town registers or criminal records as other than a deliberate flaunting by Protestants of their confessional identity, intended to be openly provocative. Mack Holt, drawing on Dijon records, describes the Huguenot habit of singing the Psalms of David very loudly in their shops and homes as a refusal to accept restrictions on the practice of their religion, which was taken (and probably intended) as an insult to their Catholic neighbours. ${ }^{9}$

However, one criminal dossier from the Burgundian town of Chalon-surSaône centres on the singing of vernacular psalms in the privacy of his house by Etienne Mathieu, a merchant. It opens a window on Protestant domestic devotion just before the Edict of Nantes (1598) and raises the question of whether a distinction between the domestic and the public was possible during the half century of religious strife in France.

psalms' important role in the literature of early modern England and colonial New England, see the essays in the collection. On the words and music of the Geneva Psalter, see 21-23 of the "Introduction".

6 Article 16 of the 1576 Edict of Beaulieu mandated that Huguenots should always be referred to by this phrase; see Holt M.P., The French Wars of Religion, 1562-1629 (Cambridge: 1995) 105. B.B. Diefendorf analyses "The Huguenot Psalter and the Faith of French Protestants in the Sixteenth Century", in Diefendorf B.B. - Hesse C. (eds.), Culture and Identity in Early Modern Europe (1500-180o): Essays in Honor of Natalie Zemon Davis (Ann Arbor: 1994) 41-63; see her notes for basic references on the history and creators of the Protestant Psalter.

7 Watson T., "Preaching, printing, psalm-singing: The making and unmaking of the Reformed church in Lyon, 1550-1572", in Mentzer R.A. - Spicer A. (eds.), Society and Culture in the Huguenot World, 1559-1685 (Cambridge: 2002) 17.

8 De Waele M., Réconcilier les français: Henri IV et la fin des troubles de religion, 1589-1598 (Québec: 2010) 18.

9 Holt M.P., "Religious Violence in Sixteenth-Century France: Moving Beyond Pollution and Purification", in Murdock G. - Roberts P. - Spicer A. (eds.), Ritual and Violence: Natalie Zemon Davis and Early Modern France, Past \& Present 214, Supplement 7 (2012) 64, 65, 67, 69. 
Etienne Mathieu, who was arrested on report of his Protestant sympathies, was adamant in his own defence that because he was not singing the psalms in public - which he admitted would be a 'scandal' and disruptive - he should not be punished. In the privacy of his house, he claimed, he could do whatever he liked. The dossier that documents arguments on both sides of the question is a hefty one, and it testifies to the contested status of the home when it was the site of forbidden religious devotions.

It is difficult to overstate the social instability of the second half of the sixteenth century in France, much of it due to the vacillation of successive royal authorities who handed down eight different Edicts of Pacification in thirtysix years - or approximately one every four years. ${ }^{10}$ Each new edict of pacification re-defined the relationship of the Protestants to the polity, sometimes in entirely opposite ways. The majority of the edicts made the new religion legal but restricted its practice severely, for example only to certain towns and on the private estates of the nobility. ${ }^{11}$ Then, a new edict would rescind even those limited guarantees, outlawing the Protestant cult entirely, banishing the pastors, and requiring all Protestants to abjure and disarm. Timothy Watson describes the plethora of contradictory edicts as the incoherence of royal policy-making.' ${ }^{2}$

As national policy vacillated, local persecution of Protestants flourished and the confused and hostile atmosphere also resulted in continuous contention over what behaviours were legal. According to Bernard Cottret, all of the edicts leading up to the Edict of Nantes in 1598 affirmed the right of liberty of conscience, with its extension in private devotion - but that was in principle. ${ }^{13}$ Much still depended upon interpretation and implementation by local authorities. In Etienne Mathieu's case, the issue was whether psalmsinging in the vernacular was allowable in his domestic space.

French society experienced cultural whiplash between 1562 and 1598, and the distinction between public and private worship was complicated during this period by the reluctance of authorities to let the Huguenots have their

10 See Stegmann A. (ed.), Édits des guerres de religion (Paris: 1979); also Haag E. - Haag E., La France Protestante, 10 vols. (Paris: 1846-59) for copies of the edicts. Sutherland N.M., The Huguenot Struggle for Recognition (New Haven - London: 1980) has useful summaries of the edicts.

11 Roberts P., Peace and Authority during the French Religious Wars, c. 1560-160o (New York: 2013) analyses the complexities of implementing the many contradictory edicts with an emphasis on the local level.

12 Watson, "Preaching, printing, psalm-singing" 15.

13 Cottret B., 1598 L'Édit de Nantes: Pour en finir avec les guerres de religion (Saint-AmandMontrond: 1997) 358-359. 
houses of worship (their 'temples') inside town walls. When Huguenots were granted permission to have a temple, it was commonly in a suburb outside the walls. Often they were not authorized to meet in a formally-designated building, and the result was clandestine worship in private houses. ${ }^{14}$

The blurring of boundaries between communal worship and domestic devotion was therefore typical of Huguenot culture in the sixteenth century, though it reached a climax in 1660 when all public worship by Protestants was forbidden in France and the temples were torn down. Huguenots who continued to practice their religion were driven indoors. As Raymond A. Mentzer and Andrew Spicer comment, 'the end of formal services initially shifted the locus of Huguenot religious culture to the domestic sphere. Although household worship had always been an important element in Reformed piety, it now assumed primacy'.15 But that development came sixty-six years after Etienne's case in 1594, a time of considerable ambiguity about what was authorized an ambiguity Etienne seems to have taken advantage of in contesting his imprisonment. The unstable legal situation provided shifting ground for religious experience and, one might add, created some flexibility in evading persecution and prosecution.

By 1594, the psalms in French had been politically-charged for half a century. The Geneva Psalter always cited by Huguenots took shape over several decades. Calvin sought out Clément Marot - the most popular poet of early sixteenth-century France - to versify the psalms for use in church worship, and editions of the collection appeared in 1539 and in the 1540s. After Marot died in 1544, Calvin asked Théodore de Bèze - a brilliant scholar, theologian, and his eventual successor as spiritual leader of the Protestants - to complete the translations and versification. ${ }^{16}$ The result was the Geneva Psalter of 1562, which came to be important for both public and private worship.

14 For a broader survey of Huguenot temples in the political landscape, see Spicer A., "QQui est de Dieu oit la parole de Dieu': The Huguenots and their temples", in Mentzer - Spicer, Society and Culture in the Huguenot World 175-192. See also Roberts P., "The Most Crucial Battles of the Wars of Religion? The Conflict over Sites for Reformed Worship in SixteenthCentury France", Archiv für Reformationsgeschichte 89 (1998) 247-267. The persecution of Protestants continued throughout the seventeenth century, until they were finally ejected from France in 1685 by the Revocation of the Edict of Nantes; Deyon S., "La destruction des temples", in Zuber R. - Theis L. (eds.), La révocation de l'Edit de Nantes et le protestantisme français en 1685: Actes du colloque de Paris (15-19 octobre 1985) (Paris: 1986) 239-259.

15 Mentzer R.A. - Spicer A., "Epilogue", in Mentzer - Spicer, Society and Culture in the Huguenot World 228.

16 For a summary of Bèze's high-profile career, see Jouanna A. - Boucher J., "Bèze, Théodore de", in Jouanna A. et al. (eds.), Histoire et Dictionnaire des Guerres de Religion (Turin: 1998) 724-726; also Dufour A., Théodore de Bèze, Histoire littéraire de la France, L'Académie des 
The early 159os were the high mark of power of the zealous Catholic League, which had taken over the town governments of Dijon and Chalon. ${ }^{17}$ Given that public singing of the psalms in the Marot/Bèze translation was the preferred mode of provocation by Huguenots, guaranteed to rile both ordinary Catholics and the authorities, Etienne Mathieu's psalm-singing could never be just a neutral act. The question was one of control over the private domestic space.

The dossier preserved in the Chalon town archives brings to vivid life the effect of these religious debates on ordinary citizens. ${ }^{18}$ More precisely, it shows how sixteenth-century Burgundians negotiated the complex and shifting cultural world in which they were living. It set the scene at the main bridge over the Saône River, where twelve citizens from the neighbourhood were on duty guarding the gate. They were at their midday break on Wednesday 21st January, sitting together at a table on the riverbank, when someone mentioned that he was so upset by his neighbour who was loudly singing the Protestant psalms at her house next door that he chastised and threatened her. At this, Etienne Mathieu (the focus of the case) commented that he wouldn't forbid his neighbour from doing what she wanted in her own house and that, as for himself, he could sing the psalms this very night and no one could stop him. Furthermore, he thought it was better to sing those psalms than to sing lubricious popular songs. Others at the table reminded him that the vernacular psalms were prohibited since they brought scandal to upstanding people (gentz de bien) and good Catholics, but Etienne stubbornly held to his point of view. The group nearly came to blows, so Etienne was arrested since - as the first document dated 22nd January explains - he was saying scandalous things against the Catholic church and no-one could tolerate the disruptive behaviours he was inciting; after all, the neighbourhood guard should maintain unity for the

Inscriptions et Belles-lettres, vol. 42 (Paris: 2002). On Marot, see Wursten D., Clément Marot and Religion: A Reassessment in the Light of his Psalm Paraphrases (Leiden: 2012). See also the many essays on the Geneva (or Huguenot) Psalter in Higman F. - Kirschleger I. (eds.), "Les Psaumes de la Réforme", Bulletin de la Société de l'Histoire du Protestantisme Français 158, 2 (2012); and Trocmé-Latter D., "The Psalms as a Mark of Protestantism: The Introduction of Liturgical Psalm-Singing in Geneva", Plainsong \& Medieval Music 20, 2 (2011) 149-167.

17 The classic study of the League in Burgundy is Drouot H., Mayenne et la Bourgogne: étude sur la Ligue, 1587-1596, 2 vols. (Dijon - Paris: 1937). However, his socio-economic analysis has been challenged; see Holt M.P., "The League in Burgundy: A 'Bourgeoisie Seconde'?", French History 17, 4 (2004) 352-366.

Archives de Chalon FF 8. 
conservation of the city. Protestants are clearly depicted in this document as troublesome, and Etienne in particular is described as a difficult character. ${ }^{19}$

The Chalon prosecutor then took over to record the testimony of four witnesses who had been at the guard dinner table. Jehan Margaud, a prosecutor of the bailliage and chancellerie of Chalon, aged 30 years, took his oath on the gospel that Etienne Mathieu was defending the so-called reformed religion as the true religion because it was in the service of God and Justice. He recounted that Etienne said those songs were agreeable to God in praising Him, and when he sang them in his home in the evening no one could stop him.

The second witness was Philibert Muguet, a Chalon surgeon, aged 34 years, who added information about the female psalm-singer and other discussion at the table about the psalms. The woman, he said, lived in a small room near the billiard game site, and she was heard at 10 o'clock in the evening loudly singing the psalms in the Marot translation. Etienne Mathieu and another Protestant sympathizer at the table then asked whether it was wrong to do this, and were told that the singing 'scandalized' the neighbours since that version of the psalms was forbidden by the Catholic church. Muguet also testified that Etienne Mathieu said that singing dissolute and lubricious songs would be more scandalous than singing the vernacular psalms, and that he could sing them himself in his home without anyone stopping him. Muguet, who was testifying, added that Etienne had better sing quietly because if he heard Etienne singing the psalms loudly he would file a protest.

The third witness was Claude Basson, a tailor aged about 35 years. In Basson's description of the scene, the first witness Jehan Margaud picked up a 'pain' probably a loaf of bread or baguette - asking how much it cost. Basson guessed it cost about two solz, at which another of the Protestant sympathizers at the table said 'My God, we should praise God for the abundance that he gives us' by singing the psalm that says 'marvellous are your deeds'. (This is the second stanza of Psalm 139). ${ }^{20}$ The tailor then said that he couldn't hear the rest of the

19 This preliminary document is written by Jacques Parise, docteur en droiz, councillor at the bailliage and chancellerie of Chalon and the mayor of the city. The greffier (town scribe) transcribed it. Given the crowded intimacy of urban living - and the evidence of Etienne Mathieu's combative personality presented by witnesses - it is quite likely that the affluent merchant was well known by town officials charged with this case.

20 Psalm 139 has a pause after an initial section that might not have been sung (as explained by Florence Poinsot of the Paris Bibliothèque de la Société de l'Histoire du Protestantisme Français). The second section beginning 'Pour vray, merveilleux sont tes faitz', expresses a favorite Huguenot sentiment of praise for God. See Le Nouveau Testament, printed at Geneva by Emeran le Melays in 1577, which has appended to it Les Psaumes de David. Mis en rime Françoise par Clément de Marot \& Théodore de Bèze (Geneva: 1577). In this edition, an Epistle by an unnamed author is followed by a Théodore de Bèze poem, then the 
conversation between the Protestant sympathizers and Margaud, since he was at the other end of the table, but he did overhear Etienne Mathieu say that he'd sung the psalms and would continue doing so.

On the 24th January at 10 a.m. in the Bishop's prison, Etienne Mathieu was interrogated by Pierre Gauthier, a lawyer who was also a town councillor and co-captain of the city, and by Gabriel Biney, the secretary of the town, at the request of Pierre Monnet, prosecutor of Chalon. Etienne identified himself as a merchant of about 62 years. He admitted to having had the conversation about the right to sing the psalms in one's own house, but he claimed he was talking about the authorized version of the psalms. He then denied any seditious talk about the so-called reformed church, although he did hear the other Protestant sympathizer propose singing the psalm that begins with the line 'marvellous are your deeds' (addressed to God). He denied most of Muguet's testimony, and when queried about the validity of the Marot/Bèze translation of the psalms he said that he left that up to those who were more learned, but he did know that the Catholic league did not sing the vernacular versions. He was somewhat vague on whether he had abjured as was mandated by the 1588 Edict of the Union, but he did say that he did the duty of a Catholic, meaning he confessed and took the sacrament at Easter and attended feast day services; just ask his confessor Mr. Guillaume Roux, the bastonnier (lay administrator) at Saint Vincent's Cathedral, Etienne suggested.

The interrogation of Etienne Mathieu was continued on 25th January, during which he said that the conversation about the psalms had not been explicit about which version was being referred to. The interrogator tried to pin him down on whether the psalms were those in the Protestant version, and whether he was defending the Protestant religion, but Etienne's responses were slippery. He said he had professed the new religion when it was permitted by the King's edict, but then, when a new edict mandated the Catholic faith, he had ceased to be Protestant. He remembered that he had been ordered to go before the King's officials at the bailliage of Chalon to abjure with many other people, but he couldn't remember if he had done so. There should be a written record if he had, he added, putting the investigatory onus back onto the authorities.

That same day there was a second round of interrogations of both the witnesses and of Etienne, evidently to see if any of the testimony was perjured.

psalms with music and prayers - a very complete book for private devotions. There are instructions on how to celebrate the various sacraments, there are the Articles of Faith, prayers for fathers and servants in the morning, a Protestant Calendar with block prints the psalms matched to the months etc. For a discussion of the many themes in the psalms that especially appealed to Huguenots, see Diefendorf, "The Huguenot Psalter" 41-63. 
When asked about the accusations of Muguet, Etienne immediately said that his deposition should not be believed because there was bad blood between them. A fourth witness, Pierre Barbier, a baker, showed up belatedly and his deposition was taken. Etienne Mathieu also impugned the credibility of Barbier's testimony, saying that they had come to blows at the bridge guard a year before, with Barbier responding that it was the day of the Chalon massacre when they were arguing about the ligueurs (zealous Catholics) versus the royalists (who supported the king). Etienne also pointed out that Barbier had been fined numerous times for not upholding bakery standards, but Barbier responded that although, yes, he had been fined, his deposition was still accurate and he was an homme de bien (an honest and upstanding man).

The case for letting Etienne out of the prison was based on his denials but also on his age and illness - he had a rheume (a cold). Also his wife was ill in bed at home. A bail of 50 escuz (reduced from 100) was paid by another merchant friend, Edme Vadot, and Etienne was liberated on 26th January, having promised to return for all future legal proceedings.

On 28th January, a week after the incident at the bridge, the first witness Jean Margaud was recalled and, when Etienne was brought in to face him, Etienne said that they also had quarrelled before, not only at the bridge, but at the Beaune gate of the town and in the Saint Jean de Maisel neighbourhood - and Etienne added that, by the way, Margaud did not allow his wife to go to see her mother (implying he was a wife-abuser). Margaud denied all these accusations.

An undated 12-page document written by Pierre Monnet, the prosecutor of Chalon, in a fancy formal hand with Latin phrases thrown in, summed up the 'definitive conclusions' in the case against Etienne Mathieu. The document summarizes the charges that Etienne was defending Protestant ideas and practices, including singing the psalms in his own house. However, the prosecutor wrote that Etienne had not admitted singing psalms in the Marot/Bèze translation but rather claimed to be singing a mixed Latin/French version authorized by the Catholic Church.

He also cited the vicar who wrote the preface to the psalter translation of the Catholics that all religions sing the psalms, including Turks, Mohammedans, Jews, Greek Orthodox and Ethiopians; the heretics in the world use the psalms in their prayers, both public and private. The prosecutor said, however, that the Catholic Church in their public prayers preferred the Latin language as more suitable and vibrant (plus propre et energique) because it expressed more precisely with less ambiguity the divine and sacred mysteries. He pointed out that the Council of Trent (the fourth session, second decretal) had also mandated Latin for official public church reading, preaching and exposition, unlike the heretics - Lutherans, Baenists, Calvinists and other sects - who use 
the vernacular. In a surprising turn, the prosecutor then admitted that Latin is only required for public worship; in private prayer, he said, the church tolerates each person speaking in his own vernacular because to God all languages are the same. And the prosecutor cited the letter of Saint Jerome to the venerable lady Marcella in support of his argument. There is nothing wrong, he reiterated, in the individual saying his prayers and singing the psalms in the French vernacular as long as he is in his private space.

That being true, however, worship in the home must be in the translation by the Paris doctors of the faculty of theology, the one approved by the Edict of King Henry II in 1547 and 1551. The translation by the Protestants Marot and Bèze was censured by the theology faculty and the Council of Trent. The prosecutor threw in the observation that those authorities also condemned using one's private worship for profane things, amorous passions, and fabulous or vain satires (ridicules) and defamatory libels. He recommended to the city council that Etienne Mathieu should take a vow of the Catholic faith and swear not to hold (either in public or private) views antithetical to the authorized religion, as well as singing the psalms only in the Catholic translation - all on pain of punishment.

On 13th February Etienne was thus officially instructed to take a vow of living and dying in the Catholic religion, according to the 1588 Edict of Henry III. Whether in public or private, it specified, Etienne must not hold propositions contrary to the Catholic religion, and he must not sing the songs in any but the authorized Catholic versions on pain of being fined 20 escuz, half to repair the church of the moat and the other half to repair the bridge.

On the 1oth March 1594, the town authorities gave their follow-up verdict: Etienne Mathieu was condemned to a fine of ten escuz, to be divided among the religious orders - the Carmelites and the Cordeliers - and the hospital, the prisoners, and the repair of the church and cemetery. In line with both canon and civil laws, Etienne was also to make his official abjuration. However, as probably the town authorities suspected, Etienne was far from sincere in his promises. A document of zoth July records a fine on him for not following up. Then on 2oth August he was also summoned to pay the expenses of the lawsuit against him.

\section{Conclusions}

Etienne Mathieu's legal tussles with the Chalon town councillors bring into relief the question of whether a distinction between public and private was salient during the religious wars of the sixteenth century. Could any religious practices in the home truly be considered 'domestic' - belonging to a domain 
off-limits to regulation by hostile authorities? As Will Coster and Andrew Spicer comment in their introduction to their collection, Sacred Space in Early Modern Europe, "There is a tension inherent in all religions between the ownership of sacred space by the individual, the institution and the community [...]. These tensions and complexities became all the more acute at the Reformation where the ownership of space and the public nature of worship became flashpoints for conflict, both theological and physical.' ${ }^{21}$ Despite Etienne's vigorous insistence that he was not disturbing the public peace by singing at home, the Chalon town council concluded that his domestic space was not off-limits to their regulation of which translation he used in his devotions. In other words, worship in the home during the wars between Catholic and Protestant was as politically charged as devotions carried out in public - and as liable to punishment. The domestic space was neither safe nor apolitical for a Protestant like Etienne - although I must say it appears that the feisty and wily merchant was up to the match with the civic and religious authorities. ${ }^{22}$

\section{Bibliography}

\section{Archival Sources}

Archives de Chalon, FF 8

\section{Literature}

Austern L.P. - McBride K.B. - Orvis D.L. (eds.), Psalms in the Early Modern World (Ashgate: 2011).

Coster W. - Spicer A. (eds.), Sacred Space in Early Modern Europe (Cambridge: 2005).

Cottret B., 1598 L'Édit de Nantes: Pour en finir avec les guerres de religion (Saint-AmandMontrond: 1997).

Diefendorf B.B., "The Huguenot Psalter and the Faith of French Protestants in the Sixteenth Century", in Diefendorf B.B. - Hesse C. (eds.), Culture and Identity in Early

21 Coster - Spicer, Sacred Space in Early Modern Europe 12-13.

22 Etienne Mathieu's daughter Abigail seems to have inherited his tenacity in pursuing her goals, although she repudiated the family's Protestantism for a socially conscious Catholicism. Married five times, with a huge fortune at her disposal, Abigail was dedicated to civic philanthropy in Chalon-sur-Saône until her death in 1638. Her public career is traced in my recent article, Ashley K., "Abigail Mathieu's Civic Charity: Social Reform and the Search for Personal Immortality", in Vitullo J. - Wolfthal D. (eds.), Money, Morality, and Culture in Late Medieval and Early Modern Europe (Burlington, VT - Farnham: 2010) 197-215. 
Modern Europe (1500-180o): Essays in Honor of Natalie Zemon Davis (Ann Arbor: 1994) 41-63.

Dufour A., Théodore de Bèze, in Histoire littéraire de la France, vol. 42 (Paris: 2002) $315^{-470 .}$

Higman F. - Kirschleger I. (eds.), "Les Psaumes de la Réforme”, Bulletin de la Société de l'Histoire du Protestantisme Français 158, 2 (2012).

Holt M.P., "Religious Violence in Sixteenth-Century France: Moving Beyond Pollution and Purification", in Murdock G. - Roberts P. - Spicer A. (eds.), Ritual and Violence: Natalie Zemon Davis and Early Modern France, Past \& Present 214, Supplement 7 (2012) $5^{2-74}$.

Le Nouveau Testament with appendix, Les Psaumes de David. Mis en rime Françoise par Clément de Marot \& Théodore de Bèze (Geneva, Abel Rivery: 1577).

Mentzer R.A. - Spicer A. (eds.), Society and Culture in the Huguenot World, 1559-1685 (Cambridge: 2002).

Reinburg V., French Books of Hours: Making an Archive of Prayer, c. 1400-1600 (Cambridge: 2012).

Roberts P., "The Most Crucial Battles of the Wars of Religion? The Conflict over Sites for Reformed Worship in Sixteenth-Century France", Archiv für Reformationsgeschicte 89 (1998) 247-267.

Roberts P., Peace and Authority during the French Religious Wars, c. 1560-160o (New York: 2013).

Stegmann A. (ed.), Édits des guerres de religion (Paris: 1979).

Sutherland N.M., The Huguenot Struggle for Recognition (New Haven: 1980).

Trocmé-Latter D., "The Psalms as a Mark of Protestantism: The Introduction of Liturgical Psalm-Singing in Geneva", Plainsong \& Medieval Music 20, 2 (2011) 149-67.

Watson T., "Preaching, printing, psalm-singing: The making and unmaking of the Reformed church in Lyon, 1550-1572", in Mentzer R.A. - Spicer A. (eds.), Society and Culture in the Huguenot World, 1559-1685 (Cambridge: 2002) 10-28.

Wieck R., Painted Prayers: The Book of Hours in Medieval and Renaissance Art (New York: 1997).

Wursten D., Clément Marot and Religion. A Reassessment in the Light of his Psalm Paraphrases (Leiden: 2012). 